\title{
Vitamin D deficiency and childhood obesity: interactions, implications, and recommendations
}

\author{
This article was published in the following Dove Press journal: \\ Nutrition and Dietary Supplements \\ 20 February 2015 \\ Number of times this article has been viewed
}

\section{Catherine A Peterson \\ Department of Nutrition and Exercise Physiology, University of Missouri- Columbia, Columbia, MO, USA}

\begin{abstract}
Vitamin D deficiency and childhood obesity have been classified as epidemics throughout the world, and both share some common risk factors including poor diet and inactivity. Observational and clinical studies show that vitamin D status and fat mass are inversely correlated. It is not clear whether vitamin D deficiency contributes to, or is a consequence of obesity, or whether there are regulatory interactions between excess adiposity and vitamin D activity. The effects of this deficiency in childhood obesity appear to have negative influences on overall health, including insulin resistance, inflammation, and impeded bone mineralization, as well as increased future risk of type 2 diabetes, cardiovascular disease, and osteoporosis. The rather ubiquitous distribution of the vitamin $\mathrm{D}$ receptor and the 25-hydroxyvitamin D $1 \alpha$-hydroxylase throughout the body, including evidence for a role of vitamin $\mathrm{D}$ in adipogenesis and adipocyte metabolism, may in part explain these widespread effects. Most of the findings to date suggest that the vitamin $\mathrm{D}$ needs of obese children are greater than the nonobese. Although ultraviolet B-induced skin synthesis is a main source of vitamin D, its use is neither feasible nor prudent due to limited sun availability for many and concerns for skin cancer. Likewise, obtaining adequate vitamin D from natural food sources alone is generally not achievable, and even in countries that allow fortification, vitamin D intakes are low. Therefore, in obese children, vitamin D supplementation is warranted. Weight loss interventions using energy restriction and physical activity may also improve the poor vitamin D status associated with obesity. More research is needed to define optimal vitamin D status in this vulnerable population, including investigations to determine the efficacy of vitamin D supplementation in attenuating the conditions associated with childhood obesity, and to further elucidate the mechanisms by which vitamin D exerts its effects on health.
\end{abstract}

Keywords: cholecalciferol, childhood overweight, hypovitaminosis D

\section{Introduction}

Childhood obesity is a major global health crisis. A systematic analysis of 1,769 reports representing 188 countries reveals that the worldwide prevalence of childhood overweight and obesity rose by nearly $50 \%$ over a span of three decades. ${ }^{1}$ Roughly 43 million children are estimated to be overweight or obese throughout the world, and another 92 million are at risk of overweight. ${ }^{2}$ If this trend continues, the global prevalence of childhood obesity is predicted to reach 60 million by $2020 .^{2}$

The implications of this crisis are numerous and far reaching, involving both the individual and society. ${ }^{3}$ For a child, there are physical health and psychosocial and functional consequences across a lifetime as studies show that childhood obesity is accompanied by an increase in associated chronic conditions such as insulin resistance (IR),
Correspondence: Catherine A Peterson Department of Nutrition and Exercise Physiology, University of MissouriColumbia, 204 Gwynn Hall, Columbia MO 652II, USA

Tel +l 5738828690

Fax +l 5738844885

Email petersonca@missouri.edu 
inflammation, hypertension, and dyslipidemia. ${ }^{4}$ Moreover, childhood obesity can predict adult illness ${ }^{5}$ and compromise longevity. ${ }^{6}$

One growing, active area of research is the association between vitamin D deficiency and childhood obesity. Individually, each has been classified as an epidemic throughout the world, and both share some common risk factors including poor diet and inactivity. ${ }^{2,7}$ Further, observational and clinical studies show that vitamin D status and fat mass are inversely correlated, ${ }^{8}$ and recent intervention trials indicate that correcting the poor vitamin D status associated with obesity may attenuate some of the comorbidities of obesity. The objective of this review is to discuss the recent literature on vitamin D and childhood obesity including their interactions and implications for health and disease.

\section{Vitamin D: the hormone, the nutrient, and its action}

Although classified as a nutrient (largely due to the timing of its discovery which coincided with the discovery of other fat-soluble vitamins), vitamin D is more fittingly described as a prohormone/hormone. ${ }^{9}$ It exists in two forms: vitamin $\mathrm{D}_{2}$ and vitamin $\mathrm{D}_{3}$. Vitamin $\mathrm{D}_{2}$, or ergocalciferol, is a photoproduct of the irradiation of ergosterol, a fungal sterol also known as provitamin $\mathrm{D}_{2}$. Vitamin $\mathrm{D}_{3}$, or cholecalciferol, is produced following the irradiation of provitamin $\mathrm{D}_{3}$ (7-dehydrocholestrol) in the epidermis and dermis layers of the skin. ${ }^{10}$ The term "vitamin D" without a subscript refers to vitamin $\mathrm{D}_{2}$, vitamin $\mathrm{D}_{3}$, or both. The primary source of vitamin $\mathrm{D}$ is from skin synthesis as there are few naturally occurring dietary sources. ${ }^{11}$

Both vitamin $\mathrm{D}_{2}$ and vitamin $\mathrm{D}_{3}$ are hydroxylated twice to become active and capable of binding to their vitamin $\mathrm{D}$ receptor (VDR). The first hydroxylation occurs in the liver via 25-hydroxylase, forming 25-hydroxyvitamin D (25(OH)D) (also known as calcidiol). This is the major circulating form of vitamin $\mathrm{D}$ and is the primary determinant of vitamin $\mathrm{D}$ status. The enzyme 25-hydroxyvitamin D $1 \alpha$-hydroxylase ( $1 \alpha$-OH-ase) converts $25(\mathrm{OH}) \mathrm{D}$ to its active form, 1,25dihydroxyvitamin $\mathrm{D}\left(1,25(\mathrm{OH})_{2} \mathrm{D}\right.$, also known as calcitriol). Although this enzyme is classically identified in the proximal tubules of the kidney, $1 \alpha-\mathrm{OH}$-ase (CYP27B1) gene expression has been demonstrated in a wide range of extrarenal tissues, including, but not limited to, immune, brain, pancreatic, and adipose tissue. ${ }^{12,13}$ Renal activation of $25(\mathrm{OH}) \mathrm{D}$ results in elevated levels of circulating $1,25(\mathrm{OH})_{2} \mathrm{D}$, which subsequently binds to the VDR in target tissues. Extrarenal formation of $1,25(\mathrm{OH})_{2} \mathrm{D}$ appears to act locally by binding to VDR present within the same or neighboring cells. These intracrine and autocrine/paracrine actions are thought to be regulated by cytokines and to be responsible for the effects of $1,25(\mathrm{OH})_{2} \mathrm{D}$ on cell proliferation, differentiation, and apoptosis. $^{14}$

Vitamin D and its metabolites are transported bound to and solubilized by plasma protein carriers. Vitamin D-binding protein (DBP), a protein primarily produced by hepatic parenchymal cells, is the major transport protein. It binds $85 \%$ of circulating $25(\mathrm{OH}) \mathrm{D}$, while albumin and lipoproteins account for the remaining $15 \% .^{15}$

Once synthesized, from renal or local production, $1,25(\mathrm{OH})_{2} \mathrm{D}$ is transported to nuclear VDR in target cells. ${ }^{16}$ The human VDR plays a central role in the biological actions of vitamin $\mathrm{D}$ as it regulates the expression of numerous genes in a largely ligand-dependent manner. ${ }^{16}$ VDRs, upon activation by $1,25(\mathrm{OH})_{2} \mathrm{D}$, form a heterodimer with retinoid $\mathrm{X}$ receptors (RXRs). These VDR-RXR heterodimers bind to vitamin D response elements of multiple genes, which results in either the transactivation or repression of these genes. ${ }^{17}$

Throughout childhood, vitamin D plays important roles in calcium and phosphorus homeostasis and bone growth/ mineralization. Vitamin D deficiency in childhood causes osteomalacia, leading to growth retardation and skeletal deformities (ie, rickets). ${ }^{10}$ More common, however, is an insidious presentation of vitamin D deficiency, which may prevent children and adolescents from reaching peak bone mass and predicted height. ${ }^{18}$

There is evidence that vitamin D is necessary for many other cellular processes. In addition to the organs responsible for calcium/phosphate homeostasis, VDRs are expressed in a variety of tissues and cells such as the hepatocytes, myocytes, adipocytes, pancreatic $\beta$-cells, and several immune cells, all of which are associated with obesity and its associated metabolic complications. ${ }^{16,19,20}$

\section{Vitamin D deficiency: reemergence, diagnosis, and prevalence in children}

Rickets, first documented in approximately 120 AD by Sorano of Ephesus, is the most recognized disease of vitamin D deficiency as it has plagued humans throughout history. ${ }^{21}$ It became especially problematic in Europe and North America during the Industrial Revolution with the related reduction in sun exposure for those living and working in urban environments. Advancements in the science of vitamin D in the mid-20th century led to public health initiatives such as food fortification, which eliminated rickets as a significant health problem in the countries that 
implemented them. ${ }^{7}$ However, in the last 10-15 years, evidence has surfaced for a reemergence of rickets in certain ethnic and minority groups in Europe and Australasia and an alarming prevalence of poor vitamin D status worldwide. ${ }^{22}$ The factors speculated to contribute to this rise in vitamin D deficiency include lower intakes of vitamin D-fortified foods, use of sunscreens/blocks, reduced time spent in outdoor activities, and air pollution. ${ }^{23}$ Moreover, our understanding of the role of vitamin D in human health has expanded into areas beyond bone and has subsequently put into question the definition of adequate vitamin D status. ${ }^{23,24}$

\section{Diagnostic criteria}

The best available indicator of vitamin D status is the serum concentration of $25(\mathrm{OH}) \mathrm{D},{ }^{25}$ although the extent to which this measurement relates to or serves as a predictor of health outcomes has not been fully elucidated. Furthermore, there is no general agreement on the required serum $25(\mathrm{OH}) \mathrm{D}$ for adequate status. For example, the Institute of Medicine (IOM) defines vitamin D deficiency, or hypovitaminosis D, as a serum $25(\mathrm{OH}) \mathrm{D}$ concentration $<50 \mathrm{nmol} / \mathrm{L}(20 \mathrm{ng} / \mathrm{mL}),{ }^{26}$ whereas the Endocrine Society has suggested that a $25(\mathrm{OH}) \mathrm{D}$ concentration between $75 \mathrm{nmol} / \mathrm{L}$ and $250 \mathrm{nmol} / \mathrm{L}(30$ $100 \mathrm{ng} / \mathrm{mL}$ ) is required for sufficiency, with the intermediate concentration range of 52-72 nmol/L (21-29 ng/mL) classified as "insufficient". ${ }^{27}$ Vitamin D status classifications within pediatric clinical practice guidelines are similarly controversial. The American Academy of Pediatrics (AAP) ${ }^{28}$ cut-off values are identical to IOM with a $25(\mathrm{OH}) \mathrm{D}$ concentration $>50.0 \mathrm{nmol} / \mathrm{L}$ considered to be "sufficient", while the Society for Adolescent Health and Medicine $(\mathrm{SAHM})^{29}$ considers a $25(\mathrm{OH}) \mathrm{D}$ serum concentration between $75-125 \mathrm{nmol} / \mathrm{L}(30-50 \mathrm{ng} / \mathrm{mL})$ to be "sufficient" for the adolescent.

\section{Childhood prevalence of vitamin $D$ deficiency}

Hypovitaminosis D is a significant problem among people of all ages around the world, ${ }^{30}$ although there are large gaps of information on the pediatric populations of some countries. ${ }^{31}$ The estimated worldwide prevalence of hypovitaminosis D in children and adolescents is rather wide, between $29 \%$ and $100 \%,{ }^{32}$ and surveys show it to be in part related to the degree of adiposity, with healthy weight at $21 \%$, overweight at $29 \%$, obese at $34 \%$, and severely obese at $49 \%{ }^{33}$ Thus, obese children are a particularly vulnerable group for poor vitamin D status, which in turn appears to exacerbate the effects of obesity alone on overall health. ${ }^{31,33,34}$

\section{Interactions and implications of vitamin D deficiency in obese children}

It is not clear whether hypovitaminosis D contributes to, or is a consequence of, obesity, or whether there are regulatory interactions between excess adiposity and vitamin D activity. Data from a prospective, population-based study following 1,226 adult participants over a decade showed that the odds of gaining more than $3.7 \mathrm{~kg}$ (75th percentile) between the second and third visits in those with $25(\mathrm{OH}) \mathrm{D}$ serum concentrations $<42 \mathrm{nmol} / \mathrm{L}(17 \mathrm{ng} / \mathrm{mL})$ was 2.37 times greater than those with higher $25(\mathrm{OH}) \mathrm{D}$ concentrations. ${ }^{35}$ This suggests that the poor vitamin D status in the obese may not be secondary to obesity but may instead precede it. In support of this, a population-based longitudinal study of children in the Brazilian Amazon found the effect of the obesityassociated gene variation (FTO rs9939609) to be more pronounced among children with insufficient vitamin D status. ${ }^{36}$ Conversely, a recent bidirectional Mendelian randomization analysis of multiple cohorts involving a total of more than 42,000 individuals provided evidence of obesity as a causal factor in the development of vitamin D deficiency but not vice versa. ${ }^{37}$ This analysis revealed that the "body mass index (BMI) allele score" created by the investigators was associated with both $\mathrm{BMI}$ and $25(\mathrm{OH}) \mathrm{D}$ concentration among study participants, and each $10 \%$ increase in BMI leads to a $4.2 \%$ decrease in $25(\mathrm{OH}) \mathrm{D}$ concentration. ${ }^{37}$ However, although both of the two "25(OH)D allele scores" were linked with serum $25(\mathrm{OH}) \mathrm{D}$ concentration, neither was associated with BMI.

\section{Conditions in obese children affected by vitamin $D$ status}

IR and inflammation are commonly seen in overweight/obese children and are predictive of the development of metabolic syndrome, type 2 diabetes mellitus (T2DM), cardiovascular disease (CVD), and perhaps osteopenia/osteoporosis. For example, reports indicate that children with these two risk factors are significantly more likely to have T2DM and CVD 25-30 years later compared with their peers. ${ }^{38,39}$

The relationship between poor vitamin D status and IR, T2DM, and metabolic syndrome is the most well studied and was first observed in obese adults. ${ }^{40}$ Similar observations have since been made in obese children. Most, although not all, show significant associations between circulating 25(OH)D concentration and indices of IR and blood glucose control; their findings have been covered in detail elsewhere. ${ }^{41}$ The very few published intervention 
trials using vitamin D supplementation to improve IR and impaired glucose tolerance in obese children or adolescents have yielded beneficial effects. ${ }^{41}$ For example, results from our 6-month randomized controlled trial (RCT) of obese adolescents (age $=14.1 \pm 2.8$ years; $\mathrm{BMI}=39.8 \pm 6.1 \mathrm{~kg} / \mathrm{m}^{2}$ ) supplemented with 4,000 IU per day showed an attenuation of IR similar to results involving the use of the drug metformin. ${ }^{42}$ By comparison, the results of a 2012 meta-analysis of the evidence on vitamin D supplementation and glycemic control in adults revealed a weak effect of vitamin D supplementation in reducing fasting glucose and improving IR in patients with T2DM or impaired glucose tolerance. ${ }^{43}$ Much of this discrepancy can be attributed to differences in methods employed, such as vitamin D dose and outcome measures, and participant characteristics, most notably body weight/ fat status, initial vitamin D status, and age. Further, it is speculated that the status of both vitamin D and parathyroid hormone (PTH) needs to be considered in evaluating the impact of vitamin D status on glucose metabolism. ${ }^{44}$ More RCTs are warranted.

The biological mechanisms by which vitamin D influences glycemic control in obesity have yet to be determined but are thought to involve enhancement of peripheral/hepatic uptake of glucose, attenuation of inflammation, and/or regulation of insulin synthesis/secretion by pancreatic $\beta$-cells. ${ }^{41}$ Moreover, data from one of the first reports to examine the association between vitamin D deficiency and IR in obese children indicated that the most clinically meaningful threshold of serum $25(\mathrm{OH}) \mathrm{D}$ concentration for the identification of IR and impaired glucose homeostasis in the obese is $50 \mathrm{nmol} / \mathrm{L}(20 \mathrm{ng} / \mathrm{mL}) .{ }^{45} \mathrm{This}$ is the cut-off used by the IOM in the definition of vitamin D deficiency.

A new systematic review of 35 studies evaluated the degree to which vitamin D and CVD risk factors are associated in obese children. ${ }^{46}$ The cross-sectional studies included in the analysis showed a relationship between $25(\mathrm{OH}) \mathrm{D}$ and systolic blood pressure but not the prospective studies. The lone RCT in the review suggested a relationship between vitamin D status and arterial stiffness. There were no associations between $25(\mathrm{OH}) \mathrm{D}$ and diastolic blood pressure or low-density lipoprotein cholesterol, and the links with high-density lipoprotein cholesterol and triglycerides were capricious.

Anther condition related to childhood obesity and metabolic disturbances is nonalcoholic fatty liver disease (NAFLD). Since both NAFLD and serum 25(OH)D concentration are associated with adiposity and IR, interest in examining their potential pathogenic link has emerged.
Pediatric NAFLD is a condition characterized by hepatic fat infiltration $>5 \%$ hepatocytes, as assessed by liver biopsy, in the absence of viral, autoimmune, and drug-/alcohol-induced liver disease. ${ }^{47}$ It is becoming one of the most common complications of childhood obesity and is strongly associated with the clinical features of IR, especially the metabolic syndrome and T2DM. ${ }^{47}$ Two separate observational studies showed that compared with non-NAFLD obese children and teens, those with NAFLD had significantly lower serum concentrations of $25(\mathrm{OH}) \mathrm{D}$, which was correlated with IR in those with NAFLD but not in those without NAFLD. ${ }^{48,49}$ Another investigation showed that lower $25(\mathrm{OH}) \mathrm{D}$ concentration is associated with NAFLD, independent of adiposity, physical activity, and IR. ${ }^{50}$ At odds with these findings, an earlier report using data on 1,630 children, aged 12-19 years, from the National Health and Examination Survey (NHANES) 2001-2004, found vitamin D status not to be independently associated with NAFLD. ${ }^{51}$ It remains to be determined whether poor vitamin D status contributes directly to the risk of developing NAFLD or if this association is confounded by hepatosteatosis, ${ }^{48}$ as the liver is a primary site of vitamin D activation.

The bone mass attained during growth is a critical determinant of the risk of osteoporosis later in life. ${ }^{52}$ Those with higher peak bone mass after adolescence have a protective advantage during normal aging and menopause when significant bone loss occurs. Although it is known that peak bone mass is determined by genetics and lifestyle factors, the effects of obesity on bone mineral accretion are not fully discerned. In contrast with adults in whom overweight/obesity is protective to bones, there is evidence that obesity in children is a risk factor for low bone mass and fractures. ${ }^{53}$ However, this phenomenon is not uniformly observed. ${ }^{54}$ Efforts of new investigations have focused on addressing the reasons for the discrepancy, including distribution of body fat (abdominal obesity), ${ }^{55}$ and/or the presence of comorbidities, such as IR, ${ }^{56}$ metabolic syndrome, ${ }^{57}$ and NAFLD. ${ }^{58}$

Factors thought to be responsible for the altered bone mass described in childhood obesity include changes in the hormonal milieu (eg, increased conversion of androstenedione to estrogen), ${ }^{59}$ and the participation of adipokines (resistin, adiponectin, leptin, osteocalcin $)^{60}$ and adipose-derived inflammatory markers (interleukin-6 [IL-6] and tumor necrosis factor- $\alpha[$ TNF- $\alpha]$ ) in bone remodeling. ${ }^{58,61}$ Another likely contributor is the poor vitamin $\mathrm{D}$ status related to obesity, via its indirect (inflammation) and/or direct (calcium homeostasis/bone mineralization) skeletal effects. 
Children have high demands for dietary calcium to support the mineralization of growing bone. It is well established that serum PTH concentration varies inversely with absorbed calcium and serum $25(\mathrm{OH}) \mathrm{D}$ concentration. It has been proposed that the point along the $25(\mathrm{OH}) \mathrm{D}$ continuum at which PTH becomes constant is an indication of the point at which calcium absorption becomes constant. ${ }^{62}$ A study of young, healthy children in Canada demonstrated that a $25(\mathrm{OH}) \mathrm{D}$ concentration of $100 \mathrm{nmol} / \mathrm{L}$ was required to see a plateau in PTH. ${ }^{63}$

\section{Adipose-endocrine response as an important link between vitamin D deficiency and obesity-related conditions}

The effect of excess body fat is theorized to 1) increase the metabolic clearance of vitamin D and its metabolites through enhanced uptake, 2) decrease the bioavailability of vitamin D once deposited in adipocytes, and/or 3) create a volumetric dilution of vitamin D due to a larger body mass. ${ }^{64,65}$ For comparison, the amount of total body fat mass of lean children (BMI for age $\leq 15$ th percentile) is described to be between $1.8 \mathrm{~kg}$ and $2.2 \mathrm{~kg}, 2.7 \mathrm{~kg}$ and $4.2 \mathrm{~kg}$, and $6 \mathrm{~kg}$ and $10 \mathrm{~kg}$, for children 3-5 years, 6-11 years, and 12-19 years of age, respectively, while the total body fat mass of overweight/ obese children (BMI for age $\geq 85$ th percentile) of similar age is reported to be more than threefold greater. ${ }^{66}$ Adipose tissue, the storage site of this excess body fat, was once thought to be inert but is now regarded as a highly metabolic endocrine organ. ${ }^{67}$ It secretes more than 260 different proteins/peptides (adipokines, chemokines, cytokines) and is a major player in glycemic control. ${ }^{68,69}$ Vitamin D appears to have a role in adipose tissue and its metabolic processes; however, the molecular basis of the interactions of $25(\mathrm{OH}) \mathrm{D}, 1,25(\mathrm{OH})_{2} \mathrm{D}$, DBP, and VDR after sequestration in adipose tissue and their regulations are not well understood.

The genes for VDR and vitamin D-metabolizing enzymes (CYP27A1, CYP27B1) have been identified in both animal and human adipocytes. ${ }^{19,70}$ Research demonstrates that both the active form, $1,25(\mathrm{OH})_{2} \mathrm{D}$, and the parent molecule, vita$\min \mathrm{D}_{3}$, influence several key adipogenic genes and transcription factors as well as lipid accumulation. ${ }^{19,70}$ Yet, the specific function of vitamin $\mathrm{D}$ in the adipogenic process remains largely ambiguous, and often contradictory, with studies showing both stimulation and inhibition of adipogenesis. ${ }^{67}$

Vitamin D metabolites also influence adipokine production and the inflammatory response in adipose tissue. ${ }^{67}$ There is convincing support for chronic inflammation as the causal link between obesity and its related metabolic conditions, such as IR, liver fat deposition, and poor bone mineralization. As adipocytes expand, they produce and secrete several inflammatory cytokines and chemokines such as TNF- $\alpha$, IL-6, monocyte chemotactic protein-1, and leptin. ${ }^{67}$ Observational studies have shown an inverse correlation between $25(\mathrm{OH}) \mathrm{D}$ concentration and several of these inflammatory cytokines. ${ }^{71,72}$ Furthermore, multiple in vivo and in vitro studies have reported that $25(\mathrm{OH}) \mathrm{D}$ downregulates the production and secretion of multiple pro-inflammatory cytokines including IL-1, IL-2, IL-6, IL-12, C-reactive protein, TNF- $\alpha$, and interferon- $\gamma \cdot{ }^{73,74}$

\section{Age and pubertal status confound the association between vitamin $D$ and childhood obesity}

From the literature on vitamin D and childhood obesity, age and pubertal status surface as significant confounders. A recent study of obese 2- to 6-year olds found an inverse relationship between child age and serum 25(OH)D concentration, ${ }^{75}$ while another in older children reported the same finding. ${ }^{76}$ Greater vitamin D intakes in younger children may provide an explanation. Data collected from NHANES 2003-2003 show that $76 \%$ and $78 \%$ of 1 - to 3 -year-old boys and girls, respectively, have total intakes (diet and supplements) above the IOM recommendations, while, in 14- to 18-year-old boys and girls, only $32 \%$ and $54 \%$, respectively, have intakes above recommendations.$^{77}$ Greater sun exposure in younger children is another feasible explanation as they engage in more outdoor playtime than older children and adolescents. ${ }^{78,79}$

Excess adiposity during childhood may advance puberty in girls and delay puberty in boys. ${ }^{80}$ Puberty is known to affect many of the metabolic conditions associated with obesity and vice versa. IR and compensatory hyperinsulinemia may represent a common thread contributing to many of the pubertal changes reported to occur with childhood obesity ${ }^{81,82}$ Two studies designed to specifically examine the effects of puberty on the association between 25(OH)D serum concentration and IR show that it does not become significant until children reach puberty. ${ }^{83,84}$ Further, an analysis of cross-sectional data of obese children required adjustments for puberty to reveal associations between vitamin D status and homeostatic model assessment - insulin resistance (HOMA-IR) ${ }^{85}$ and the aforementioned report of very young obese children found no association between vitamin D status and IR. ${ }^{75}$

\section{Effects of vitamin D status on weight loss and vice versa}

Preliminary results in obese adults hinted at a more favorable response (greater body fat loss) to energy restriction 
in those with adequate vitamin D status. ${ }^{86}$ However, a 2014 meta-analysis of RCTs using vitamin D supplementation without imposing energy restriction revealed only a small effect of improved vitamin D status on BMI but not fat mass. ${ }^{87}$ Interestingly, this meta-analysis also indicated that studies in older people and men were less likely to show an effect on BMI or fat mass. There is a paucity of data available on the effect of vitamin D supplementation on weight loss in children. In one study of overweight children undergoing diet counseling, high milk consumption (primary source of vitamin D in the USA) did not lead to greater weight loss but attenuated insulin action. ${ }^{88}$ (Unfortunately, serum $25(\mathrm{OH}) \mathrm{D}$ was not measured, so associations with vitamin D status could not be assessed.) Likewise, in our RCT of obese adolescents also undergoing diet counseling, although vitamin D supplementation decreased IR, neither body weight or waist circumference changed over 6 months. ${ }^{42}$ Of relevance, an earlier RCT of healthy girls, 10-17 years of age, found that premenarcheal participants given weekly oral doses of vitamin $\mathrm{D}$ for 1 year had significant increases in lean body mass and height, with no changes in body weight, suggesting a decrease in body fat (although not reported). ${ }^{89}$ Despite these data, however, the overall evidence of positive effects of vitamin D on weight or fat loss is thus far underwhelming.

Reports have looked at the effect of weight loss on vitamin D status. In a cross-sectional study of obese children who achieved a reduction in overweight over a 1-year time period, serum PTH decreased, and serum 25(OH)D increased significantly compared to obese children without weight loss. ${ }^{90}$ Similar observations have been described in adult weight loss studies. ${ }^{91,92}$

\section{Recommendations for treating vitamin D deficiency in obese children}

The IOM-recommended dietary allowance is $600 \mathrm{IU}(15 \mu \mathrm{g})$ daily for children 1-18 years of age. ${ }^{26}$ Recommendations of pediatric medical societies such as the AAP or the European Society for Pediatric Gastroenterology, Hepatology, and Nutrition are below this dose, ${ }^{93,94}$ while the Endocrine Society and SAHM guidelines suggest that this same age group may need up to $1,000 \mathrm{IU}(15-25 \mu \mathrm{g})$ per day (Table 1). ${ }^{27,29}$ This disagreement reflects different goals and views on current evidence. ${ }^{95}$

The above recommendations are generally intended for healthy populations and do not reflect the unique needs of disease groups or of those with diagnosed vitamin D deficiency.

\section{Vitamin D needs and dose response in the obese}

With the high prevalence of hypovitaminosis D among obese children, the requirements for most obese youth would likely

Table I Comparison of selected pediatric recommendations for vitamin D maintenance and treatment of deficiency

\begin{tabular}{|c|c|c|c|}
\hline Organization & $\begin{array}{l}\text { General recommendation } \\
\text { (IU per day)* }\end{array}$ & $\begin{array}{l}\text { Upper limit } \\
\text { (IU per day) }\end{array}$ & $\begin{array}{l}\text { Treatment strategy for } \\
\text { vitamin } D \text { deficiency }\end{array}$ \\
\hline Institute of Medicine (IOM) $)^{26}$ & $\begin{array}{l}I-3 \text { y: } 600 \\
4-8 y: 600 \\
9-18 \text { y: } 600\end{array}$ & $\begin{array}{l}2,500 \\
3,000 \\
4,000\end{array}$ & $\mathrm{~N} / \mathrm{A}$ \\
\hline $\begin{array}{l}\text { American Academy of } \\
\text { Pediatrics (AAP) }\end{array}$ & I-I8 y: 400 & $N / A$ & $\begin{array}{l}\text { Children with serum } 25(\mathrm{OH}) \mathrm{D} \\
\leq 37.5 \mathrm{nmol} / \mathrm{L}(\mathrm{I} 5 \mathrm{ng} / \mathrm{mL}) \\
5,000 \mathrm{IU} \text { per day until stores } \\
\text { are replenished }\end{array}$ \\
\hline $\begin{array}{l}\text { European Society for Pediatric } \\
\text { Gastroenterology, Hepatology, } \\
\text { and Nutrition (ESPGHAN) })^{93}\end{array}$ & $\begin{array}{l}\text { Healthy diet with vitamin D- } \\
\text { containing foods and } \\
\text { adequate outdoor activities }\end{array}$ & $\begin{array}{l}I-10 \text { y: } 2,000 \\
I I-18 \text { y: } 4,000\end{array}$ & $N / A$ \\
\hline $\begin{array}{l}\text { Society for Adolescent Health } \\
\text { and Medicine (SAHM })^{29}\end{array}$ & Adolescents: $600-1,000$ & 4,000 & $\begin{array}{l}\text { Adolescents with serum } 25(\mathrm{OH}) \mathrm{D} \\
\leq 50 \mathrm{nmol} / \mathrm{L}(20 \mathrm{ng} / \mathrm{mL}) \text {, } \\
50,000 \mathrm{IU} \text { weekly for } 8 \text { weeks } \\
\text { or until serum } 25(\mathrm{OH}) \mathrm{D} \\
>50 \mathrm{nmol} / \mathrm{L}\end{array}$ \\
\hline Endocrine Society ${ }^{27}$ & $I-18$ y: $600-1,000$ & 4,000 & $\begin{array}{l}\text { Children with serum } 25(\mathrm{OH}) \mathrm{D} \\
\leq 50 \mathrm{nmol} / \mathrm{L}, 2,000 \mathrm{IU} \text { per day } \\
\text { or } 50,000 \mathrm{IU} \text { weekly of vitamin } \mathrm{D} \\
\text { for at least } 6 \text { weeks or until } \\
\text { serum } 25(\mathrm{OH}) \mathrm{D}>50 \mathrm{nmol} / \mathrm{L}\end{array}$ \\
\hline
\end{tabular}

Note: $* 40 \mathrm{IU}=\mathrm{I} \mu \mathrm{g}$.

Abbreviations: IU, international units; y, years; N/A, not available; 25(OH)D, 25-hydroxyvitamin D. 
fall under a different set of recommendations. For children with documented deficiency (serum $25(\mathrm{OH}) \mathrm{D} \leq 37.5 \mathrm{nmol} / \mathrm{L}$ [15 $\mathrm{ng} / \mathrm{mL}])$, the AAP recommends 5,000 IU (124 $\mu \mathrm{g})$ per day until stores are replenished. ${ }^{28}$ Findings from our study of obese adolescents support this higher dose. After 3 months of supplementation with 4,000 IU $(100 \mu \mathrm{g})$, none of the participants were of vitamin D-“deficient” status, and after 6 months, 93\% were of "sufficient" status $(>75 \mathrm{nmol} / \mathrm{L}$ or $30 \mathrm{ng} / \mathrm{L}) .{ }^{42}$ By comparison, the Endocrine Society guidelines recommend 2,000 IU $(50 \mu \mathrm{g})$ per day or 50,000 IU $(1,250 \mu \mathrm{g})$ weekly of vitamin D for at least 6 weeks or until serum concentrations of $25(\mathrm{OH}) \mathrm{D}$ are above $50 \mathrm{nmol} / \mathrm{L}(20 \mathrm{ng} / \mathrm{mL}) .{ }^{27}$ A new report investigating 25,000 IU weekly vitamin D supplementation of deficient/insufficient obese 8- to 18-year olds over 9 weeks found that it was well tolerated and resulted in advancement to "sufficient" status in more than $84 \%$ of participants. ${ }^{96}$ However, given the altered metabolism of vitamin D reported in the obese, ${ }^{64,97}$ it is questionable whether the dose required for maintenance in nonobese is the same as that required by the obese.

The obese are approximately half as efficient in using vitamin $\mathrm{D}$ compared to their lean counterparts. ${ }^{97,98}$ It has been estimated that $100 \mathrm{IU}$ are required for every $2.5 \mathrm{nmol} / \mathrm{L}$ $(1 \mathrm{ng} / \mathrm{mL})$ increase in serum $25(\mathrm{OH}) \mathrm{D}$ concentration in the nonobese, ${ }^{99}$ whereas, in our study of obese adolescents, it took approximately $205 \mathrm{IU}$ - more than double - of vitamin D for the same incremental increase. ${ }^{42}$ As further evidence of a higher dose required in obese children, a vitamin D supplementation study found that vitamin D deficiency persisted in $24 \%$ of obese versus $11 \%$ of nonobese African-American children given 400 IU per day for 4 weeks. ${ }^{100}$ Collectively, these findings argue for a separate set of guidelines for obese children and adolescents.

\section{Meeting vitamin D needs through sun, food, or supplement sources}

Vitamin D synthesis in the skin depends on the photoconversion of 7-dehydrocholestrol to previtamin $\mathrm{D}_{3}$ by ultraviolet $\mathrm{B}$ (UVB) light (wavelength $=209-315 \mathrm{~nm}$ ). ${ }^{101}$ Once formed, previtamin D3 undergoes heat-induced isomerization to vitamin $\mathrm{D}_{3} \cdot{ }^{10}$ Vitamin $\mathrm{D}$ toxicity from skin synthesis is highly unlikely as prolonged exposure to sunlight photodegrades previtamin $\mathrm{D}_{3}$ to biologically inert isomers. ${ }^{102,103}$ Several factors affect the skin's ability to produce vitamin $\mathrm{D}_{3}$. Season, latitude, and time of day affect vitamin $\mathrm{D}_{3}$ production by altering the absorption of UVB photons by the ozone layer. ${ }^{101,102}$ In the winter, the solar zenith angle of the sun is more diagonal at high latitudes causing the total number of photons reaching the Earth's surface to diminish. During the day, UVB radiation is most intense when the sun is at its highest point, which occurs at midday. The application of sunscreen/block (sun protection factor as low as seven to eight blocks approximately $95 \%$ of previtamin $\mathrm{D}_{3}$ production), ${ }^{104}$ possessing greater amounts of melanin in one's skin (acting as a natural sunscreen), ${ }^{105}$ and the use of clothing or other body covering also significantly decrease the production of vitamin D in the skin. ${ }^{102,103,106}$

UVB synthesis is one of the main sources of vitamin $\mathrm{D}$ in most populations tracked; however, due to the limited sun availability throughout the year in many locations and concerns for skin cancers, relying on this source for the treatment of vitamin D deficiency in childhood obesity is neither practical nor prudent. Likewise, obtaining adequate vitamin D from natural food sources alone is generally not achievable as only a limited number of foods naturally contain vitamin D. Among them, the most vitamin D rich are fish liver oils, fish, and organ meats, and to a lesser extent, egg yolks and sun-dried mushrooms. ${ }^{107}$

For those countries in which high levels of fish are not consumed, the only alternative to UVB light exposure is the use of fortified foods or dietary supplements. Commonly fortified foods include breakfast cereals, milk, milk products, grain products, pastas, margarine, and some brands of orange juice. ${ }^{11}$ In the USA, most vitamin D intake from foods is provided through fortification. ${ }^{108}$ In New Zealand, Australia, Canada, and the UK, fewer foods are fortified, and the prevalence of insufficiency is as low as or lower than observed in the USA. ${ }^{11,109,110}$

Even in countries that allow fortification, vitamin D intakes are low in those with dietary practices that limit the consumption of fortified foods. ${ }^{109}$ For example, the consumption of milk, the most common vehicle for vitamin D fortification, generally declines with increasing age in children. ${ }^{111}$ Therefore, in obese children, a population with apparently greater needs and prone to deficiency, vitamin D supplementation is warranted.

Both forms of the vitamin, $\mathrm{D}_{2}$ or $\mathrm{D}_{3}$, can be used as a food fortificant or dietary supplement, although $\mathrm{D}_{3}$ dominates. ${ }^{11}$ Some reports indicate that $\mathrm{D}_{2}$ is not as effective as $\mathrm{D}_{3}$, while others show no difference. ${ }^{12,113}$ In the USA, dietary supplements are readily available as over-the-counter (OTC) preparations and can contain up to 5,000 IU per capsule (which is not the case universally, eg, Australia). ${ }^{114}$ The $\mathrm{D}_{3}$ content of OTC is highly variable with potencies ranging from $9 \%$ to $146 \%$ of label claims. ${ }^{115}$ For medical use, prescription-grade supplements are available in the $\mathrm{D}_{2}$ form only. ${ }^{116}$ Intramuscular (IM) 
vitamin $\mathrm{D}_{2}$ is also used to treat low-vitamin $\mathrm{D}$ status. The oral route is more efficacious than IM, but administration method should be based on patient's choice, compliance, and availability as IM preparations are not available in all countries. ${ }^{117}$

Ingested vitamin D is presumed to follow the same fate as dietary lipids, although new data reveal that digestive and absorptive processes may be more complex than previously recognized as large interindividual variation in postprandial responses to vitamin D has been observed. ${ }^{118,119}$ During digestion, vitamin $\mathrm{D}$ is transferred to the mixed micelles generated by the lipolysis of dietary fat. ${ }^{120}$ Upon uptake through the brush border, vitamin D becomes incorporated into chylomicrons along with the other products of fat digestion, and approximately $80 \%$ is absorbed into the lymphatic system. ${ }^{121} \mathrm{D}_{2}$ and $\mathrm{D}_{3}$ forms are similarly absorbed by the enterocyte. ${ }^{122-124}$ Total fat content of a meal does not appear to significantly alter vitamin D absorption; ${ }^{125}$ however, several fat-soluble molecules including dietary cholesterol, phytosterols, and vitamins A, E, and $\mathrm{K}$ have been shown to inhibit or compete with vitamin D for absorption. ${ }^{119,126,127}$ Further, any health conditions characterized by fat malabsorption can increase the risk for vitamin D deficiency. ${ }^{128}$

Vitamin D can accumulate throughout the body with adipose tissue as its primary storage site. It has a half-life of 4-6 weeks, ${ }^{129}$ although higher doses can lead to a long residence time. ${ }^{130,131}$ One laboratory performed a series of experiments to determine the relation between serum vitamin $\mathrm{D}_{3}$ and vitamin $\mathrm{D}$ status, as measured by serum concentration of $25(\mathrm{OH}) \mathrm{D}$, in healthy adults after the oral administration of vitamin $\mathrm{D}_{3}$ across a broad range of intakes. Doses of 0-11,000 IU per day showed the increases in serum $25(\mathrm{OH}) \mathrm{D}$ to be biphasic: rapid conversion of vitamin $\mathrm{D}_{3}$ to $25(\mathrm{OH}) \mathrm{D}$ at physiological doses and slower rate of conversion at higher doses. ${ }^{132}$

\section{Monitoring for vitamin D toxicity}

Although vitamin D toxicity, defined as a serum concentration of $25(\mathrm{OH}) \mathrm{D} \geq 375 \mathrm{nmol} / \mathrm{L}(150 \mathrm{ng} / \mathrm{mL})$, in children is rare, health care providers should monitor children receiving treatment doses exceeding the upper ranges currently recommended. ${ }^{133}$ The IOM set a daily tolerable upper intake level of 2,500 IU (63 $\mu \mathrm{g})$ for 1- to 3-year olds, 3,000 IU (75 $\mu \mathrm{g})$ for 4- to 8-year olds, and 4,000 IU (100 $\mu \mathrm{g})$ for 14- to 18 -year olds, ${ }^{26}$ while the SAHM and Endocrine Society have endorsed an upper limit of 4,000 IU for all childhood age groups. ${ }^{27,29}$ There is insufficient evidence to guide the frequency of testing; however, it has been suggested that measurements of serum $25(\mathrm{OH}) \mathrm{D}$ be taken no more than every 6 months. ${ }^{133}$ In children with serum $25(\mathrm{OH}) \mathrm{D}$ concentrations above $375 \mathrm{nmol} / \mathrm{L}(150 \mathrm{ng} / \mathrm{mL})$, serum calcium concentrations should also be monitored. ${ }^{133}$

\section{Conclusion}

Vitamin D deficiency is prevalent in childhood obesity. Excess adiposity is linked with poor vitamin D status, and the effects of this deficiency during obesity appear to have several health implications, including IR, inflammation, and compromised bone growth/mineralization. The rather ubiquitous distribution of VDR and the $1 \alpha-\mathrm{OH}$-ase throughout the body, including evidence of a role of vitamin D in adipogenesis and adipocyte metabolism, may in part explain these widespread consequences. Whether poor vitamin $\mathrm{D}$ status is a cause or an effect of obesity is not known; however, most of the findings to date suggest that the vitamin D needs of obese children are greater than the nonobese, and that weight loss can improve vitamin D status. Further research is required to define optimal vitamin D status and corresponding intake recommendations in this deficiency-prone population. Other investigations should focus on determining the clinical efficacy of vitamin D supplementation on the attenuation of the metabolic symptoms and conditions associated with childhood obesity. Finally, work is needed on the elucidation of the mechanisms by which vitamin D exerts its effects on obesity/adipose tissue and health.

\section{Disclosure}

The author reports no conflicts of interest in this work.

\section{References}

1. Ng M, Fleming T, Robinson M, et al. Global, regional, and national prevalence of overweight and obesity in children and adults during 1980-2013: a systematic analysis for the Global Burden of Disease Study 2013. Lancet. 2014;384(9945):766-781.

2. Wang Y, Lim H. The global childhood obesity epidemic and the association between socio-economic status and childhood obesity. Int Rev Psychiatry. 2012;24:176-188.

3. Committee on Accelerating Progress in Obesity Prevention, Food and Nutrition Board, Institute of Medicine. Accelerating Progress in Obesity Prevention: Solving the Weight of the Nation. Washington, DC: National Academies Press; 2012.

4. Abrams P, Levitt Katz LE. Metabolic effects of obesity causing disease in childhood. Curr Opin Endocrinol Diabetes Obes. 2011;18:23-27.

5. Campbell F, Conti G, Heckman JJ, et al. Early childhood investments substantially boost adult health. Science. 2014;343:1478-1485.

6. Olshansky SJ, Passaro DJ, Hershow RC, et al. A potential decline in life expectancy in the United States in the 21st century. N Engl J Med. 2005;352:1138-1145.

7. Holick MF, Chen TC. Vitamin D deficiency: a worldwide problem with health consequences. Am J Clin Nutr. 2008;87:1080S-1086S.

8. Foss YJ. Vitamin D deficiency is the cause of common obesity. Med Hypotheses. 2009;72:314-321.

9. DeLuca HF. History of the discovery of vitamin D and its active metabolites. Bonekey Rep. 2014;3:479. 
10. Holick MF. Vitamin D. In: Shils ME, Shike M, Ross AC, Caballero B, Cousins RJ, editors. Modern Nutrition in Health and Disease. 10th ed. Baltimore, MD: Lippincott Williams and Wilkins; 2006:376-395.

11. Macdonald HM. Contributions of sunlight and diet to vitamin D status. Calcif Tissue Int. 2013;92:163-176.

12. Li J, Byrne ME, Chang E, et al. 1alpha,25-Dihydroxyvitamin D hydroxylase in adipocytes. J Steroid Biochem Mol Biol. 2008;112:122-126.

13. Zehnder D, Bland R, Williams MC, et al. Extrarenal expression of 25-hydroxyvitamin d(3)-1 alpha-hydroxylase. J Clin Endocrinol Metab. 2001;86:888-894.

14. Jones G. Extrarenal vitamin D activation and interactions between vitamin $\mathrm{D}(2)$, vitamin $\mathrm{D}(3)$, and vitamin D analogs. Annu Rev Nutr. 2013;33:23-44.

15. Schwartz JB, Lai J, Lizaola B, et al. A comparison of measured and calculated free $25(\mathrm{OH})$ vitamin D levels in clinical populations. J Clin Endocrinol Metab. 2014;99:1631-1637.

16. Wang Y, Zhu J, DeLuca HF. Where is the vitamin D receptor? Arch Biochem Biophys. 2012;523:123-133.

17. Haussler MR, Whitfield GK, Kaneko I, et al. Molecular mechanisms of vitamin D action. Calcif Tissue Int. 2013;92:77-98.

18. Kremer R, Campbell PP, Reinhardt T, Gilsanz V. Vitamin D status and its relationship to body fat, final height, and peak bone mass in young women. J Clin Endocrinol Metab. 2009;94:67-73.

19. Ding C, Gao D, Wilding J, Trayhurn P, Bing C. Vitamin D signalling in adipose tissue. Br J Nutr. 2012;108:1915-1923.

20. Mitri J, Dawson-Hughes B, Hu FB, Pittas AG. Effects of vitamin D and calcium supplementation on pancreatic beta cell function, insulin sensitivity, and glycemia in adults at high risk of diabetes: the calcium and vitamin D for diabetes mellitus (CaDDM) randomized controlled trial. Am J Clin Nutr. 2011;94:486-494.

21. O'Riordan JL, Bijvoet OL. Rickets before the discovery of vitamin D. Bonekey Rep. 2014;3:478.

22. Prentice A. Vitamin D deficiency: a global perspective. Nutr Rev. 2008;66:S153-S164.

23. Raiten DJ, Picciano MF. Vitamin D and health in the 21 st century: bone and beyond. Executive summary. Am J Clin Nutr. 2004;80: 1673S-1677S

24. Holick MF. Vitamin D: extraskeletal health. Endocrinol Metab Clin North Am. 2010;39:381-400.

25. Brannon PM, Yetley EA, Bailey RL, Picciano MF. Overview of the conference "vitamin D and health in the 21 st century: an update". Am J Clin Nutr. 2008;88:483S-490S.

26. Ross AC. The 2011 report on dietary reference intakes for calcium and vitamin D. Public Health Nutr. 2011;14:938-939.

27. Holick MF, Binkley NC, Bischoff-Ferrari HA, et al; Endocrine Society. Evaluation, treatment, and prevention of vitamin D deficiency: an endocrine society clinical practice guideline. J Clin Endocrinol Metab. 2011;96:1911-1930.

28. Misra M, Pacaud D, Petryk A, Collett-Solberg PF, Kappy M. Vitamin D deficiency in children and its management: review of current knowledge and recommendations. Pediatrics. 2008;122:398-417.

29. Harel Z, Cromer B, DiVasta AD, Gordon CM. Recommended vitamin $D$ intake and management of low vitamin $D$ status in adolescents: a position statement of the society for adolescent health and medicine. J Adolesc Health. 2013;52:801-803.

30. Hossein-nezhad A, Holick MF. Vitamin D for health: a global perspective. Mayo Clin Proc. 2013;88:720-755.

31. Wahl DA, Cooper C, Ebeling PR, et al. A global representation of vitamin D status in healthy populations. Arch Osteoporos. 2012;7: $155-172$.

32. Shin YH, Shin HJ, Lee YJ. Vitamin D status and childhood health. Korean J Pediatr. 2013;56:417-423.

33. Turer CB, Lin H, Flores G. Prevalence of vitamin D deficiency among overweight and obese US children. Pediatrics. 2013;131:e152-e161.

34. Bellone S, Esposito S, Giglione E, et al. Vitamin D levels in a paediatric population of normal weight and obese subjects. J Endocrinol Invest. 2014;37(9):805-809.
35. Gonzalez-Molero I, Rojo-Martinez G, Morcillo S, et al. Hypovitaminosis D and incidence of obesity: a prospective study. Eur J Clin Nutr. 2013;67:680-682.

36. Lourenco BH, Qi L, Willett WC, Cardoso MA. FTO genotype, vitamin D status, and weight gain during childhood. Diabetes. 2014;63: 808-814.

37. Vimaleswaran KS, Berry DJ, Lu C, et al; Genetic Investigation of Anthropometric Traits-GIANT Consortium. Causal relationship between obesity and vitamin D status: bi-directional mendelian randomization analysis of multiple cohorts. PLoS Med. 2013;10: e1001383.

38. Morrison JA, Friedman LA, Gray-McGuire C. Metabolic syndrome in childhood predicts adult cardiovascular disease 25 years later: the Princeton Lipid Research Clinics Follow-up Study. Pediatrics. 2007;120: 340-345.

39. Morrison JA, Friedman LA, Wang P, Glueck CJ. Metabolic syndrome in childhood predicts adult metabolic syndrome and type 2 diabetes mellitus 25 to 30 years later. J Pediatr. 2008;152:201-206.

40. Pittas AG, Lau J, Hu FB, Dawson-Hughes B. The role of vitamin D and calcium in type 2 diabetes. A systematic review and meta-analysis. J Clin Endocrinol Metab. 2007;92:2017-2029.

41. Peterson CA, Tosh AK, Belenchia AM. Vitamin D insufficiency and insulin resistance in obese adolescents. Ther Adv Clin Endocrinol Metab. 2014;5(6):166-189.

42. Belenchia AM, Tosh AK, Hillman LS, Peterson CA. Correcting vitamin D insufficiency improves insulin sensitivity in obese adolescents: a randomized controlled trial. Am J Clin Nutr. 2013;97:774-781.

43. George PS, Pearson ER, Witham MD. Effect of vitamin D supplementation on glycaemic control and insulin resistance: a systematic review and meta-analysis. Diabet Med. 2012;29:e142-e150.

44. Kramer CK, Swaminathan B, Hanley AJ, et al. Prospective associations of vitamin D status with beta-cell function, insulin sensitivity and glycemia: the impact of parathyroid hormone status. Diabetes. 2014; 63(11):3868-3879.

45. Alemzadeh R, Kichler J, Babar G, Calhoun M. Hypovitaminosis D in obese children and adolescents: relationship with adiposity, insulin sensitivity, ethnicity, and season. Metabolism. 2008;57:183-191.

46. Dolinsky DH, Armstrong S, Mangarelli C, Kemper AR. The association between vitamin $\mathrm{D}$ and cardiometabolic risk factors in children: a systematic review. Clin Pediatr (Phila). 2013;52:210-223.

47. Marzuillo P, Del Giudice EM, Santoro N. Pediatric non-alcoholic fatty liver disease: new insights and future directions. World J Hepatol. 2014;6:217-225.

48. Pirgon O, Cekmez F, Bilgin H, Eren E, Dundar B. Low 25-hydroxyvitamin D level is associated with insulin sensitivity in obese adolescents with non-alcoholic fatty liver disease. Obes Res Clin Pract. 2013;7: e275-e283.

49. Yildiz I, Erol OB, Toprak S, et al. Role of vitamin D in children with hepatosteatosis. J Pediatr Gastroenterol Nutr. 2014;59:106-111.

50. Black LJ, Jacoby P, She Ping-Delfos WC, et al. Low serum 25hydroxyvitamin D concentrations associate with non-alcoholic fatty liver disease in adolescents independent of adiposity. $J$ Gastroenterol Hepatol. 2014;29:1215-1222.

51. Katz K, Brar PC, Parekh N, Liu YH, Weitzman M. Suspected nonalcoholic fatty liver disease is not associated with vitamin d status in adolescents after adjustment for obesity. J Obes. 2010;2010:496829.

52. National Institutes of Health. Osteoporosis prevention, diagnosis, and therapy. NIH Consens Statement. 2000;17:1-45.

53. Whiting SJ. Obesity is not protective for bones in childhood and adolescence. Nutr Rev. 2002;60:27-30.

54. Leonard MB, Shults J, Wilson BA, Tershakovec AM, Zemel BS. Obesity during childhood and adolescence augments bone mass and bone dimensions. Am J Clin Nutr. 2004;80:514-523.

55. Junior IF, Cardoso JR, Christofaro DG, Codogno JS, de Moraes AC, Fernandes RA. The relationship between visceral fat thickness and bone mineral density in sedentary obese children and adolescents. BMC Pediatr. 2013;13:37. 
56. Pirgon O, Bilgin H, Tolu I, Odabas D. Correlation of insulin sensitivity with bone mineral status in obese adolescents with nonalcoholic fatty liver disease. Clin Endocrinol (Oxf). 2011;75:189-195.

57. Nobrega da Silva V, Goldberg TB, Mosca LN, Bisi Rizzo AC, Teixeira AS, Corrente JE. Metabolic syndrome reduces bone mineral density in overweight adolescents. Bone. 2014;66:1-7.

58. Pacifico L, Bezzi M, Lombardo CV, et al. Adipokines and C-reactive protein in relation to bone mineralization in pediatric nonalcoholic fatty liver disease. World J Gastroenterol. 2013;19:4007-4014.

59. Klein KO, Larmore KA, de LE, Brown JM, Considine RV, Hassink SG. Effect of obesity on estradiol level, and its relationship to leptin, bone maturation, and bone mineral density in children. $J$ Clin Endocrinol Metab. 1998:83:3469-3475.

60. Dimitri P, Wales JK, Bishop N. Adipokines, bone-derived factors and bone turnover in obese children; evidence for altered fat-bone signalling resulting in reduced bone mass. Bone. 2011;48:189-196.

61. Boucher-Berry C, Speiser PW, Carey DE, et al. Vitamin D, osteocalcin, and risk for adiposity as comorbidities in middle school children. $J$ Bone Miner Res. 2012;27:283-293.

62. Heaney RP. The Vitamin D requirement in health and disease. J Steroid Biochem Mol Biol. 2005;97:13-19.

63. Maguire JL, Birken C, Thorpe KE, Sochett EB, Parkin PC. Parathyroid hormone as a functional indicator of vitamin D sufficiency in children. JAMA Pediatr. 2014;168:383-385.

64. Drincic AT, Armas LA, Van Diest EE, Heaney RP. Volumetric dilution, rather than sequestration best explains the low vitamin D status of obesity. Obesity (Silver Spring). 2012;20:1444-1448.

65. Wolden-Kirk H, Overbergh L, Gysemans C, et al. Unraveling the effects of $1,25 \mathrm{OH} 2 \mathrm{D} 3$ on global gene expression in pancreatic islets. J Steroid Biochem Mol Biol. 2013;136:68-79.

66. Mei Z, Grummer-Strawn LM, Pietrobelli A, Goulding A, Goran MI, Dietz WH. Validity of body mass index compared with other bodycomposition screening indexes for the assessment of body fatness in children and adolescents. Am J Clin Nutr. 2002;75:978-985.

67. Mutt SJ, Hypponen E, Saarnio J, Jarvelin MR, Herzig KH. Vitamin D and adipose tissue-more than storage. Front Physiol. 2014;5:228.

68. Lehr S, Hartwig S, Sell H. Adipokines: a treasure trove for the discovery of biomarkers for metabolic disorders. Proteomics Clin Appl. 2012;6:91-101.

69. Lehr S, Hartwig S, Lamers D, et al. Identification and validation of novel adipokines released from primary human adipocytes. Mol Cell Proteomics. 2012;11:M111.

70. Zoico E, Franceschetti G, Chirumbolo S, et al. Phenotypic shift of adipocytes by cholecalciferol and 1alpha, 25 dihydroxycholecalciferol in relation to inflammatory status and calcium content. Endocrinology. 2014; $155: 4178-4188$.

71. Peterson CA, Heffernan ME. Serum tumor necrosis factor-alpha concentrations are negatively correlated with serum $25(\mathrm{OH}) \mathrm{D}$ concentrations in healthy women. J Inflamm (Lond). 2008;5:10.

72. Laird E, McNulty H, Ward M, et al. Vitamin D deficiency is associated with inflammation in older Irish adults. J Clin Endocrinol Metab. 2014;99:1807-1815.

73. Vilarrasa N, Vendrell J, Maravall J, et al. Is plasma 25(OH) D related to adipokines, inflammatory cytokines and insulin resistance in both a healthy and morbidly obese population? Endocrine. 2010;38: $235-242$.

74. Ding C, Wilding JP, Bing C. 1,25-dihydroxyvitamin D3 protects against macrophage-induced activation of NFkappaB and MAPK signalling and chemokine release in human adipocytes. PLoS One. 2013;8:e61707.

75. Creo AL, Rosen JS, Ariza AJ, Hidaka KM, Binns HJ. Vitamin D levels, insulin resistance, and cardiovascular risks in very young obese children. J Pediatr Endocrinol Metab. 2013;26:97-104.

76. Smotkin-Tangorra M, Purushothaman R, Gupta A, Nejati G, Anhalt H, Ten S. Prevalence of vitamin D insufficiency in obese children and adolescents. J Pediatr Endocrinol Metab. 2007;20:817-823.
77. Bailey RL, Dodd KW, Goldman JA, et al. Estimation of total usual calcium and vitamin D intakes in the United States. J Nutr. 2010;140: $817-822$.

78. Al-Othman A, Al-Musharaf S, Al-Daghri NM, et al. Effect of physical activity and sun exposure on vitamin D status of Saudi children and adolescents. BMC Pediatr. 2012;12:92.

79. Lagunova Z, Porojnicu AC, Lindberg FA, Aksnes L, Moan J. Vitamin D status in Norwegian children and adolescents with excess body weight. Pediatr Diabetes. 2011;12:120-126.

80. Burt Solorzano CM, McCartney CR. Obesity and the pubertal transition in girls and boys. Reproduction. 2010;140:399-410.

81. Travers SH, Jeffers BW, Bloch CA, Hill JO, Eckel RH. Gender and tanner stage differences in body composition and insulin sensitivity in early pubertal children. J Clin Endocrinol Metab. 1995;80:172-178.

82. Hannon TS, Janosky J, Arslanian SA. Longitudinal study of physiologic insulin resistance and metabolic changes of puberty. Pediatr Res. 2006;60:759-763.

83. Buyukinan M, Ozen S, Kokkun S, Saz EU. The relation of vitamin D deficiency with puberty and insulin resistance in obese children and adolescents. J Pediatr Endocrinol Metab. 2012;25:83-87.

84. Khadgawat R, Thomas T, Gahlot M, et al. The effect of puberty on interaction between vitamin $\mathrm{D}$ status and insulin resistance in obese Asian-Indian children. Int J Endocrinol. 2012;2012:173581.

85. Kelly A, Brooks LJ, Dougherty S, Carlow DC, Zemel BS. A crosssectional study of vitamin D and insulin resistance in children. Arch Dis Child. 2011;96:447-452.

86. Ortega RM, Aparicio A, Rodríguez-Rodríguez E, et al. Preliminary data about the influence of vitamin D status on the loss of body fat in young overweight/obese women following two types of hypocaloric diet. Br J Nutr. 2008;100:269-272.

87. Pathak K, Soares MJ, Calton EK, Zhao Y, Hallett J. Vitamin D supplementation and body weight status: a systematic review and meta-analysis of randomized controlled trials. Obes Rev. 2014;15:528-537.

88. St-Onge MP, Goree LL, Gower B. High-milk supplementation with healthy diet counseling does not affect weight loss but ameliorates insulin action compared with low-milk supplementation in overweight children. J Nutr. 2009;139:933-938.

89. El-Hajj Fuleihan G, Nabulsi M, Tamim H, et al. Effect of vitamin D replacement on musculoskeletal parameters in school children: a randomized controlled trial. J Clin Endocrinol Metab. 2006;91: 405-412.

90. Reinehr T, de Sousa G, Alexy U, Kersting M, Andler W. Vitamin D status and parathyroid hormone in obese children before and after weight loss. Eur J Endocrinol. 2007;157:225-232.

91. Rock CL, Emond JA, Flatt SW, et al. Weight loss is associated with increased serum 25-hydroxyvitamin D in overweight or obese women. Obesity (Silver Spring). 2012;20:2296-2301.

92. Tzotzas T, Papadopoulou FG, Tziomalos K, et al. Rising serum 25-hydroxy-vitamin D levels after weight loss in obese women correlate with improvement in insulin resistance. J Clin Endocrinol Metab. 2010;95:4251-4257.

93. Braegger C, Campoy C, Colomb V, et al; ESPGHAN Committee on Nutrition. Vitamin D in the healthy European paediatric population. J Pediatr Gastroenterol Nutr. 2013;56:692-701.

94. Wagner CL, Greer FR. Prevention of rickets and vitamin D deficiency in infants, children, and adolescents. Pediatrics. 2008;122:1142-1152.

95. Pramyothin P, Holick MF. Vitamin D supplementation: guidelines and evidence for subclinical deficiency. Curr Opin Gastroenterol. 2012;28:139-150.

96. Radhakishun NN, van Vliet M, Poland DC, et al. Efficacy and tolerability of a high loading dose (25,000 IU weekly) vitamin D3 supplementation in obese children with vitamin D insufficiency/deficiency. Horm Res Paediatr. 2014;82:103-106.

97. Wortsman J, Matsuoka LY, Chen TC, Lu Z, Holick MF. Decreased bioavailability of vitamin D in obesity. Am J Clin Nutr. 2000;72: 690-693. 
98. Dhaliwal R, Mikhail M, Feuerman M, Aloia JF. The vitamin D dose response in obesity. Endocr Pract. 2014;20:1258-1264.

99. Holick MF, Biancuzzo RM, Chen TC, et al. Vitamin D2 is as effective as vitamin D3 in maintaining circulating concentrations of 25-hydroxyvitamin D. J Clin Endocrinol Metab. 2008;93:677-681.

100. Rajakumar K, Fernstrom JD, Holick MF, Janosky JE, Greenspan SL. Vitamin D status and response to Vitamin D(3) in obese vs nonobese African American children. Obesity (Silver Spring). 2008;16: 90-95.

101. Holick MF, Jenkins M. The UV Advantage. New York: ibooks; 2003.

102. Webb AR, Engelsen O. Calculated ultraviolet exposure levels for a healthy vitamin D status. Photochem Photobiol. 2006;82: 1697-1703.

103. Wacker M, Holick MF. Sunlight and Vitamin D: a global perspective for health. Dermatoendocrinol. 2013;5:51-108.

104. Holick MF, Matsuoka LY, Wortsman J. Regular use of sunscreen on vitamin D levels. Arch Dermatol. 1995;131:1337-1339.

105. Matsuoka LY, Wortsman J, Haddad JG, Kolm P, Hollis BW. Racial pigmentation and the cutaneous synthesis of vitamin D. Arch Dermatol. 1991;127:536-538.

106. Hall LM, Kimlin MG, Aronov PA, et al. Vitamin D intake needed to maintain target serum 25-hydroxyvitamin D concentrations in participants with low sun exposure and dark skin pigmentation is substantially higher than current recommendations. J Nutr. 2010;140:542-550.

107. Schmid A, Walther B. Natural vitamin D content in animal products Adv Nutr. 2013;4:453-462.

108. Holden JM, Lemar LE, Exler J. Vitamin D in foods: development of the US Department of Agriculture database. Am J Clin Nutr. 2008;87: 1092S-1096S.

109. Calvo MS, Whiting SJ, Barton CN. Vitamin D intake: a global perspective of current status. J Nutr. 2005;135:310-316.

110. Whiting SJ, Green TJ, Calvo MS. Vitamin D intakes in North America and Asia-Pacific countries are not sufficient to prevent vitamin D insufficiency. J Steroid Biochem Mol Biol. 2007;103:626-630.

111. Dror DK, Allen LH. Dairy product intake in children and adolescents in developed countries: trends, nutritional contribution, and a review of association with health outcomes. Nutr Rev. 2014;72:68-81.

112. Biancuzzo RM, Clarke N, Reitz RE, Travison TG, Holick MF. Serum concentrations of 1,25-dihydroxyvitamin D2 and 1,25-dihydroxyvitamin D3 in response to vitamin D2 and vitamin D3 supplementation. J Clin Endocrinol Metab. 2013;98:973-979.

113. Tripkovic L, Lambert H, Hart K, et al. Comparison of vitamin D2 and vitamin D3 supplementation in raising serum 25-hydroxyvitamin D status: a systematic review and meta-analysis. Am J Clin Nutr. 2012;95: 1357-1364.

114. Bilinski K, Talbot P. Vitamin d supplementation in australia: implications for the development of supplementation guidelines. J Nutr Metab. 2014;2014:374208

115. LeBlanc ES, Perrin N, Johnson JD Jr, Ballatore A, Hillier T. Overthe-counter and compounded vitamin $\mathrm{D}$ : is potency what we expect? JAMA Intern Med. 2013;173:585-586.

116. Demetriou ET, Travison TG, Holick MF. Treatment with 50,000 IU vitamin $\mathrm{D}(2)$ every other week and effect on serum 25 -hydroxyvitamin $\mathrm{D}(2), 25$-hydroxyvitamin $\mathrm{D}(3)$, and total 25-hydroxyvitamin $\mathrm{D}$ in a clinical setting. Endocr Pract. 2012;18:399-402.
117. Zabihiyeganeh M, Jahed A, Nojomi M. Treatment of hypovitaminosis D with pharmacologic doses of cholecalciferol, oral vs intramuscular; an open labeled RCT. Clin Endocrinol (Oxf). 2013;78:210-216.

118. Masson CJ, Plat J, Mensink RP, et al. Fatty acid- and cholesterol transporter protein expression along the human intestinal tract. PLoS One. 2010;5:e10380.

119. Reboul E, Goncalves A, Comera C, et al. Vitamin D intestinal absorption is not a simple passive diffusion: evidences for involvement of cholesterol transporters. Mol Nutr Food Res. 2011;55:691-702.

120. Rautureau M, Rambaud JC. Aqueous solubilisation of vitamin D3 in normal man. Gut. 1981;22:393-397.

121. Reboul E. Intestinal absorption of vitamin D: from the meal to the enterocyte. Food Funct. 2015.

122. Armas LA, Hollis BW, Heaney RP. Vitamin D2 is much less effective than vitamin D3 in humans. J Clin Endocrinol Metab. 2004;89: 5387-5391.

123. Biancuzzo RM, Young A, Bibuld D, et al. Fortification of orange juice with vitamin $\mathrm{D}(2)$ or vitamin $\mathrm{D}(3)$ is as effective as an oral supplement in maintaining vitamin D status in adults. Am J Clin Nutr. 2010;91: $1621-1626$.

124. Romagnoli E, Mascia ML, Cipriani C, et al. Short and long-term variations in serum calciotropic hormones after a single very large dose of ergocalciferol (vitamin D2) or cholecalciferol (vitamin D3) in the elderly. J Clin Endocrinol Metab. 2008;93:3015-3020.

125. Wagner D, Sidhom G, Whiting SJ, Rousseau D, Vieth R. The bioavailability of vitamin D from fortified cheeses and supplements is equivalent in adults. $J$ Nutr. 2008;138:1365-1371.

126. Borel P, Caillaud D, Cano NJ. Vitamin D bioavailability: state of the art. Crit Rev Food Sci Nutr. 2013.

127. Goncalves A, Gleize B, Bott R, et al. Phytosterols can impair vitamin D intestinal absorption in vitro and in mice. Mol Nutr Food Res. 2011; 55(Suppl 2):S303-S311.

128. Holick MF. Vitamin D deficiency. N Engl J Med. 2007;357:266-281.

129. Heaney RP, Davies KM, Chen TC, Holick MF, Barger-Lux MJ. Human serum 25-hydroxycholecalciferol response to extended oral dosing with cholecalciferol. Am J Clin Nutr. 2003;77:204-210.

130. Rosenstreich SJ, Rich C, Volwiler W. Deposition in and release of vitamin D3 from body fat: evidence for a storage site in the rat. $J$ Clin Invest. 1971;50:679-687.

131. Wu F, Staykova T, Horne A, et al. Efficacy of an oral, 10-day course of high-dose calciferol in correcting vitamin $\mathrm{D}$ deficiency. $N Z \mathrm{Med} J$. 2003;116:U536.

132. Heaney RP, Armas LA, Shary JR, Bell NH, Binkley N, Hollis BW. 25-Hydroxylation of vitamin D3: relation to circulating vitamin D3 under various input conditions. Am J Clin Nutr. 2008;87: 1738-1742.

133. Vogiatzi MG, Jacobson-Dickman E, DeBoer MD. Vitamin D supplementation and risk of toxicity in pediatrics: a review of current literature. J Clin Endocrinol Metab. 2014;99:1132-1141.
Nutrition and Dietary Supplements

\section{Publish your work in this journal}

Nutrition and Dietary Supplements is an international, peer-reviewed, open access journal focusing on research into nutritional requirements in health and disease, impact on metabolism and the identification and optimal use of dietary strategies and supplements necessary for normal growth and development. The journal welcomes papers covering

\section{Dovepress}

original research, basic science, clinical \& epidemiological studies, reviews and evaluations, guidelines, expert opinion and commentary, case reports and extended reports. The manuscript management system is completely online and includes a very quick and fair peer-review system, which is all easy to use. 